\title{
Sikap Peduli Lingkungan Peserta Didik di MAN-1 Pekanbaru Sebagai Sekolah Adiwiyata
}

\author{
Istiqomah \\ Guru MAN-1 Pekanbaru \\ e-mail: istiqomah7827@grad.unri.ac.id
}

\begin{abstract}
Current environmental problems continue to experience a serious increase. One way to reduce the threat of pollution is to change the outlook and attitudes of students to be more concerned about the environment. Adiwiyata school program is one way that can be followed to achieve these goals. This study aims to analyze the environmental attitudes of students in MAN-1 Pekanbaru who have held the status of Adiwiyata school since 2010. The research was conducted at MAN-1 Pekanbaru with a sample of 270 people using survey methods. The environmental care attitude questionnaire was compiled based on 5 indicators namely attitudes towards waste, attitudes towards energy indicators, attitudes towards water, land and air indicators, attitudes towards flora and fauna indicators and attitudes towards humans and the social environment. The results of the analysis show that the highest attitude indicator is on the attitude indicator towards humans and the social environment with an average value of 4.15, followed by an attitude indicator towards energy with an average of 3.97, an indicator of attitude towards waste of 3.79, an indicator of attitude towards air, air and land of 3.64 and indicators of attitudes towards flora and fauna of 3.57. While the environmental care category was dominated by the good category at $87.4 \%$, the very good category at $10.37 \%$ and the low attitude category at $2.22 \%$.
\end{abstract}

Key Words: The attitude of caring for the environment, Adiwiyata, Environmental Education

MAN 1 Pekanbaru merupakan lembaga pendidikan Islam yang berada di bawah naungan Kementerian Agama. Sebagai satuan pendidikan tingkat menengah yang berciri khas agama Islam, MAN 1 diarahkan untuk menjadi pusat penanaman dan pengembangan budaya dan nilai-nilai luhur seperti religius, jujur, toleransi, disiplin, kerja keras, kreatif, mandiri, demokratis, rasa ingin tahu, semangat kebangsaan, cinta tanah air, menghargai prestasi, komunikatif, cinta damai, gemar membaca, peduli sosial serta peduli terhadap lingkungan.

Sebagai institusi pendidikan pertama di bawah Kementerian Agama yang didirikan di Provinsi Riau, MAN 1 Pekanbaru terus menerus meningkatkan kualitas pendidikan guna mewujudkan sumber daya manusia yang kompetitif dan berketerampilan melalui berbagai program ungulan dan program pembiasaan. Beberapa program unggulan yang terdapat di MAN-1 diantaranya adalah, pengembangan kemampuan berbahasa Inggris dan Arab, pengembangan program melanjutkan pendidikan studi ke timur tengah bagi lulusan, pengembangan kelompok riset, pengembangan keterampilan skill seperti merakit robot, pengembangan kelas olimpiade dan program unggulan lainnya. Sementara itu, program pembiasaan mencakup kegiatan yang bersifat pembinaan sikap dan karakter peserta didik yang dilakukan sepanjang waktu. Bentuk kegiatan Pembiasaan yang diterapkan di MAN 1 merupakan kegiatan yang bersifat: 1). Rutin, yaitu kegiatan yang dilakukan secara terjadwal, seperti: upacara bendera, sholat jama'ah, pemeliharaan kebersihan dan kesehatan diri, 2). Spontan, adalah kegiatan yang dilakukan tanpa ada jadwal khusus, seperti: pembentukan perilaku memberi salam, membuang sampah pada tempatnya, dan 3). Keteladanan, adalah kegiatan dalam bentuk perilaku sehari-hari seperti: berpakaian rapi, berbahasa yang baik, rajin membaca Al-Quran dan buku, dan selalu menjaga serta memelihara kelestarian lingkungan. 
Salah satu program pembiasaan yang telah dilakukan sejak tahun 2010 di MAN-1 adalah mengikuti program Adiwiyata yang telah dicanangkan Kementerian Pendidikan Nasional dan Kementerian Lingkungan Hidup. Program Adiwiyata merupakan program sekolah peduli dan berbudaya lingkungan yang bertujuan mewujudkan warga sekolah yang bertanggung jawab melalui tata kelola sekolah yang baik untuk mendukung pembangunan berkelanjutan. Pedoman pelaksanaan Program Adiwiyata sendiri tertuang dalam peraturan menteri lingkungan hidup nomor 05 tahun 2013(KLH, 2014).

Berbagai kegiatan yang telah dilaksanakan untuk mendukung program Adiwiyata, yakni : 1). Melaksanakan program 8R (reduce, reuse, recycle, replant, rethink, respace, refuse, repair), 2). Melaksanakan program kantin sehat, 3). Menjalin Kerjasama madrasah dengan dinas kesehatan (puskesmas), 4). Memperingati kegiatan hari-hari lingkungan dan perlombaan bertema menjaga kelestarian lingkungan, 5). Pemasangan spanduk dan flamfet ajakan menjaga lingkungan serta 6). Menjalin kerjasama dengan sekolah sekolah lain yang juga mengikuti program Adiwiyata.

Tujuan Program Adiwiyata sendiri adalah menciptakan kondisi yang baik bagi sekolah untuk menjadi tempat pembelajaran dan penyadaran warga sekolah, sehingga dikemudian hari warga sekolah tersebut dapat turut bertanggungjawab dalam upaya-upaya penyelamatan lingkungan hidup dan pembangunan berkelanjutan. Program dan kegiatan yang dikembangkan harus berdasarkan norma-norma dasar dan berkehidupan yang meliputi antara lain: Kebersamaan, Keterbukaan, Kejujuran, Keadilan, dan Kelestarian Fungsi Lingkungan Hidup dan Sumber Daya Alam (Bihd, 2011)

Keuntungan yang diperoleh sekolah dalam mengikuti Program Adiwiyata adalah: 1). Meningkatkan efisiensi dalam pelaksanaan kegiatan operasional sekolah dan penggunaan berbagai sumber daya, 2). Meningkatkan penghematan sumber dana melalui pengurangan konsumsi berbagai sumber daya dan energi. 3). Meningkatkan kondisi belajar mengajar yang lebih nyaman dan kondusif bagi semua warga sekolah. 4). Menciptakan kondisi kebersamaan bagi semua warga sekolah. 5). Meningkatkan upaya menghindari berbagai resiko dan dampak negative pencemaran lingkungan dimasa yang akan datang dan 6 . Menjadi tempat pembelajaran bagi generasi muda tentang nilai- nilai pemeliharaan dan pengelolaan lingkungan hidup yang baik dan benar (Panduan Adiwiyata, 2011).

Salah satu program Adiwiyata adalah memasukkan pelajaran pendidikan lingkungan hidup (PLH) kedalam struktur kurikulum. Menurut Adisenjaya (2008) beberapa tujuan PLH adalah: 1). Membangun kesadaran, yaitu memberi dorongan kepada setiap individu untuk memperoleh kesadaran dan kepekaan terhadap lingkungan dan masalahnya, 2). Peningkatan pengetahuan, yaitu membantu setiap individu untuk memperoleh berbagai pengalaman dan pemahaman dasar tentang lingkungan dan masalahnya, 3). Membentuk sikap, yaitu membantu setiap individu untuk memperoleh seperangkat nilai dan kemampuan mendapatkan pilihan yang tepat serta mengembangkan perasaan yang peka terhadap lingkungan dan memberikan motivasi untuk berperan serta secara aktif dalam peningkatan dan perlindungan lingkungan, 4). Meningkatkan partisipasi, yaitu memberikan motivasi kepada setiap individu untuk berperan serta secara aktif dalam pemecahan masalah lingkungan dan 5). Sebagai bahan evaluasi yaitu mendorong individu agar memiliki kemampuan mengevaluasi pengetahuan lingkungan ditinjau dari segi ekologi, sosial, ekonomi dan faktorfaktor pendidikan lainnya. Melalui pembelajaran PLH di sekolah Adiwiyata, diharapkan akan meningkatkan sikap dan kepedulian lingkungan peserta didik (Iswari \& Suyud, 2017). Menurut Kose (2011), pembelajaran PLH juga dapat mengubah pengetahuan, sikap, dan perilaku peserta didik agar lebih positif terhadap lingkungan

Sikap adalah suatu perasaan ataupun suatu cara bereaksi terhadap suatu perangsangan yang diberikan. Sebagai reaksi maka sikap selalu berhubungan dengan senang (like) atau tidak senang (dislike), melaksanakan atau menghindari sesuatu (Purwanto, 2007). Sementara menurut Asrori (2007) sikap merupakan kecendrungan untuk bereaksi terhadap orang, lembaga, atau peristiwa baik secara positif maupun negative.

Menurut pandangan teory belajar Gestalt, timbulnya sikap dan tingkah laku terjadi akibat interaksi individu dengan 
lingkungan dan menggutamakan segi pemahaman (Insight). Menurut teori belajar Behavioristic, perubahan sikap merupakan hasil dari proses belajar (Suryabrata, 2002). Beberapa ahli psikologi kognitif juga menambahkan bahwa sikap atau tingkah laku sering didasari sejauh mana pengetahuan mereka tentang sikap yang ingin diubah, selain adanya reward dan punish (Wasty, 2003). Berdasarkan teori-teori belajar tersebut dapat disimpulkan bahwa perubahan sikap dan tingkah laku dapat terjadi karena adanya pemahaman tentang sesuatu, dimana pemahaman didapat dari serangkaian proses belajar.

Sikap peduli lingkungan adalah suatu perasaan yang dimiliki seseorang untuk memperbaiki dan mengelola lingkungan secara benar dan bermanfaat, sehingga dapat dinikmati secara terus menerus tanpa merusak keadaannya, turut menjaga dan melestarikan sehingga ada manfaat yang berkesinambungan (Kemendiknas, 2010). Adanya pemahaman yang diberikan tentang lingkungan, diharapkan muncul kesadaran untuk belajar bertanggung jawab, dan bersikap positif terhadap lingkungan. Lebih lanjut, peserta didik inilah yang nantinya akan menjadi pemimpin dan membuat kebijakan dalam memelihara dan melestarikan lingkungan (Campbel et al., 1999 ; Lake et al., 2010).

Namun saat ini belum ada kajian tentang bagaimana sikap peduli lingkungan peserta didik MAN-1 Pekanbaru yang telah mengikuti program Adiwiyata. Sikap peduli lingkungan peserta didik penting diketahui untuk mengevaluasi sejauh mana program Adiwiyata memberikan pengaruh positif terhadap sikap peserta didik agar lebih peduli terhadap lingkungan. Karena itu penelitian ini bertujuan untuk menganalisis bagaimana tingkat sikap peduli lingkungan peserta didik di MAN-1 Pekanbaru. Hasil penelitian diharapkan dapat menjadi bahan masukan bagi kepala madrasah untuk dapat membuat kebijakan bagi pelaksanaan dan pengembangan pelaksanaan program Adiwiyata, menjadi bahan evaluasi bagi seluruh komponen warga madrasah dan menjadi pedoman bagi kegiatan-kegiatan Adiwiyata berikutnya.

\section{BAHAN DAN METODE}

\section{Pendekatan Penelitian}

Penelitian ini merupakan penelitian kuantitatif dengan metode survey. Metode survey digunakan untuk mendapatkan data dari tempat tertentu secara alamiah. Data yang didapat selanjutnya akan dianalisis dan hasilnya di generalisasikan pada populasi.

Populasi dalam penelitian ini adalah seluruh peserta didik MAN-1 Pekanbaru tahun ajaran 2018-2019, yang berjumlah 1145 orang.

Teknik pengambilan sampel yang digunakan adalah secara random sampling. Penentuan jumlah sampel yang akan digunakan ditentukan dengan rumus :

$$
\mathbf{n i}=\mathbf{N i} / \mathbf{N} \times \mathbf{n}
$$

Sampel berjumlah 270 orang, terdiri dari kelas X sebanyak 88 orang, kelas XI 101 orang dan kelas XII sebanyak 81 orang.

\section{Tempat dan Waktu Penelitian}

Penelitian ini dilaksanakan di MAN-1 Pekanbaru, J1. Bandeng N0 51A. Dilaksanakan dari Bulan Januari hingga April 2019.

\section{Metode Pengumpulan Data}

Pengumpulan data dilakukan dengan penyebaran angket skala linkert, terdiri dari 25 pernyataan yang disusun atas 5 indikator. observasi sikap peduli lingkungan dan wawancara dengan guru dan peserta didik

\section{Penyusunan instrument sikap peduli lingkungan}

Instrumen disusun berdasarkan 5 indikator sikap peduli ligkungan, diadaptasi dari hasil riset Febrinawati \& Ahmad (2016). Terdiri dari 25 butir pernyataan berupa 14 item positif dan 11 item negatif. Indikator sikap peduli lingkungan dan pernyataan positif dan negatif masing-masing disajikan pada Tabel 1 dan 2 . 
Tabel 1. Indikator sikap peduli lingkungan

\begin{tabular}{clc}
\hline NO & \multicolumn{1}{c}{ INDIKATOR } & NO SOAL \\
\hline $\mathbf{1}$ & Pengelolaan sampah & $4,9,14,17,21$ \\
$\mathbf{2}$ & Sikap terhadap energy & $3,7,12,13,18,25$ \\
$\mathbf{3}$ & $\begin{array}{l}\text { Sikap terhadap air, } \\
\text { udara dan tanah }\end{array}$ & $2,6,8,19,23,24$ \\
$\mathbf{4}$ & $\begin{array}{l}\text { Sikap terhadap flora } \\
\text { dan fauna }\end{array}$ & $11,15,20,22$ \\
$\mathbf{5}$ & $\begin{array}{l}\text { Sikap terhadap } \\
\text { manusia dan }\end{array}$ & $1,5,10,16$ \\
& lingkungan sosial & \\
\hline
\end{tabular}

Tabel 2. Item pernyaataan sikap positif dan negative

\begin{tabular}{lc}
\hline \multicolumn{1}{c}{ Item pernyataan } & N0 soal \\
\hline Positif & $1,5,7,8,9,12,14,16,17$ \\
& $, 18,21,23,24,25$ \\
Negatif & $2,3,4,6,10,11,13,15$, \\
& $19,20,22$ \\
\hline
\end{tabular}

\section{Metode Analisis Data}

Setiap item pernyataan positif yang dijawab sangat setuju $=5$, setuju $=4$, tidak tahu $=3$, tidak setuju=2 dan sangat tidak setuju=1, sementara untuk pernyataan negative, sangat setuju $=1$, setuju $=2$, tidak tahu $=3$, tidak setuju $=4$ dan sangat tidak setuju $=5$.

Untuk analisis sikap peduli lingkungan digunakan rumus yang diadaptasi dari Campbel, 1999.

$A=\frac{\sum S}{N} \times 100$

Dimana :

$\mathrm{A}=$ Sikap (Attitude) peduli Lingkungan $\sum \mathrm{S}=$ Jumlah skor total jawaban responden $\mathrm{N}=$ Skor maksimal

Interpretasi sikap peduli lingkungan didasarkan pada Tabel 3.

Tabel 3. Kategori sikap peduli lingkungan

\begin{tabular}{clc}
\hline No & $\begin{array}{c}\text { Kategori Sikap terhadap } \\
\text { lingkungan }\end{array}$ & $\begin{array}{c}\text { Range } \\
\text { skor }\end{array}$ \\
\hline $\mathbf{1}$ & Sangat baik & $\geq 94$ \\
$\mathbf{2}$ & Baik & $63,5-93,75$ \\
$\mathbf{3}$ & Rendah & $31,25-62,5$ \\
$\mathbf{4}$ & Apatis/ tidak peduli & $<31,25$ \\
\hline
\end{tabular}

Diadaptasi dari Campbel, 1999.

\section{HASIL}

Setelah dilakukan penyebaran angket dan pengolahan data maka selanjutya dilakukan analisis terhadap capaian per item pernyataaan sikap peduli lingkungan, capaian sikap per indikator, dan mengkonsultasikan skor yang didapat pada skala kategori sikap peduli lingkungan. Tabel 4. Menyajikan skor sikap peduli lingkungan peserta didik per item pernyataan.

Tabel 4. Skor sikap peduli lingkungan per item

\begin{tabular}{|c|c|c|}
\hline No & Penyataan & $\begin{array}{c}\text { Skor } \\
\text { rata-rata }\end{array}$ \\
\hline 1 & $\begin{array}{l}\text { Kualitas kesehatan para ibu hamil } \\
\text { perlu ditingkatkan }\end{array}$ & 4.75 \\
\hline 2 & $\begin{array}{l}\text { Saya tidak pernah cemas dengan } \\
\text { pemenuhan kebutuhan air saya, karena } \\
\text { bumi kita terdiri dari } 97 \% \text { air }\end{array}$ & 3.35 \\
\hline 3 & $\begin{array}{l}\text { Saya tidak perlu menghemat energi, } \\
\text { karena energi di alam berjumlah tidak } \\
\text { terbatas (sumber energi utamanya } \\
\text { adalah matahari) }\end{array}$ & 4.06 \\
\hline 4 & $\begin{array}{l}\text { Lupa membuang botol bekas } \\
\text { minuman pada tempat sampah, } \\
\text { merupakan suatu perbuatan yang } \\
\text { dapat dimaafkan, lagi pula nantinya } \\
\text { akan dibersihkan oleh petugas } \\
\text { kebersihan }\end{array}$ & 4.19 \\
\hline 5 & $\begin{array}{l}\text { Kita harus mengurangi angka } \\
\text { kematian balita }\end{array}$ & 4.39 \\
\hline 6 & $\begin{array}{l}\text { Saya rasa, membangun septictank } \\
\text { dengan jarak } 3 \text { meter dari sumber air } \\
\text { (sumur) tidak masalah dengan } \\
\text { pertimbangan lahan tempat tinggal } \\
\text { yang sempit }\end{array}$ & 3.49 \\
\hline 7 & $\begin{array}{l}\text { Saya terbiasa mematikan lampu dan } \\
\text { alat penerang lainnya jika tidak } \\
\text { dibutuhkan }\end{array}$ & 4.60 \\
\hline 8 & $\begin{array}{l}\text { Menurut saya membajak sawah } \\
\text { dengan mesin pembajak (traktor) } \\
\text { dapat merusak struktur tanah }\end{array}$ & 3.27 \\
\hline 9 & $\begin{array}{l}\text { Saya biasa menggunakan kertas bekas } \\
\text { yang sisi belakangnya masih kosong } \\
\text { sebagai kertas coretan misalnya untuk } \\
\text { perhitungan dalam matematika }\end{array}$ & 4.41 \\
\hline 10 & $\begin{array}{l}\text { Menurut saya, atmosfer kita yang luas } \\
\text { mampu menetralisir gas buangan dari } \\
\text { kegiatan manusia di litosfer bumi }\end{array}$ & 3.34 \\
\hline 11 & $\begin{array}{l}\text { Bakteri dan jamur harus dimusnahkan } \\
\text { demi menjaga kesehatan manusia }\end{array}$ & 2.95 \\
\hline 12 & $\begin{array}{l}\text { Bersepeda ke sekolah bukan sesuatu } \\
\text { yang berat bagi saya karena } \\
\text { bersepeda dapat mengurangi polusi } \\
\text { udara }\end{array}$ & 4.04 \\
\hline 13 & $\begin{array}{l}\text { Saya akan memacu kendaraan } \\
\text { bermotor saya di atas } 60 \mathrm{~km} / \text { jam agar } \\
\text { cepat sampai dan tidak terlambat }\end{array}$ & 3.25 \\
\hline
\end{tabular}


masuk kelas

14 Saya terbiasa memisahkan sampah organic dan non organic sebelum dibuang

15 Saya bisa memesan beberapa menu makanan andalan sebuah restoran/kedai meskipun nantinya makanan tersebut tidak habis saya makan. Bagi saya tidak masalah makanan itu tidak habis, karena saya telah membayarnya.

16 Saat berada di luar ruangan, saya akan menggunakan lotion yang mengandung pelindung dari UV A yaitu lotion yang mengandung SPF

17 Saya menolak diberi plastik pembungkus belanjaan jika saya hanya membeli satu botol air minum ukuran sedang

18 Cara saya menghemat BBM salah satunya dengan memakai bus umum saat pergi jalan-jalan

19 Menurut saya, kegiatan mengurangi penggunaan alat yang mengandung CFC tidak perlu dilakukan, sebab klorin dari CFC yang terdahulu sudah terlanjur banyak di atmosfer dan sampai sekarang masih terus merusak ozon

20 Lebih praktis menggunakan pestisida dibandingkan dengan mencari predator alami untuk membasmi hama

21 Membakar sampah organik merupakan salah satu cara yang tidak tepat

22 Kegiatan konservasi terhadap gajah, harimau, maupun hewan langka lainnya tidak memberikan manfaat apapun bagi kehidupan saya

23 Saya yakin bahwa tanaman dapat menahan air dalam tanah

24 Bagi saya pribadi, menghemat air adalah hal yang sangat mudah dilakukan

25 Menjadikan kotoran sapi menjadi energi alternatif tidak sulit dilakukan

Dari 25 item sikap peduli lingkungan sebagian besar menunjukkan rata-rata sikap setuju dan tidak tahu. Terdapat 10 item yang menyatakan setuju terhadap pernyataan yang ditanyakan pada angket. Selanjutnya dilakukan analisis terhadap capaian per indikator sikap peduli lingkungan yang disajikan pada Tabel 5.
Tabel 5. Sikap peduli lingkungan peserta didik per indikator.

\begin{tabular}{llc}
\hline N0 & \multicolumn{1}{c}{$\begin{array}{c}\text { Indikator sikap peduli } \\
\text { lingkungan }\end{array}$} & $\begin{array}{c}\text { Rata-rata } \\
\text { skor }\end{array}$ \\
\hline $\mathbf{1}$ & Sikap terhadap sampah & 3.79 \\
$\mathbf{2}$ & Sikap terhadap energy & 3.97 \\
$\mathbf{3}$ & Sikap terhadap flora dan fauna & 3.57 \\
$\mathbf{4}$ & Sikap terhadap udara, tanah dan & 3.64 \\
& air & \\
$\mathbf{5}$ & Sikap terhadap lingkugan sosial & 4.15 \\
& dan manusia & \\
\hline
\end{tabular}

Dari Tabel 5 diatas, didapatkan hasil bahwa peserta didik di MAN-1 memiliki sikap peduli lingkungan paling baik pada indikator sikap terhadap lingkungan sosial dan manusia, diikuti pada indikator sikap terhadap energi, indikator sikap terhadap sampah, indikator sikap terhadap udara tanah dan air serta yang terendah adalah pada indikator sikap terhadap flora dan fauna. Grafik perbandingan capaian tiap indikator disajikan pada gambar 1.

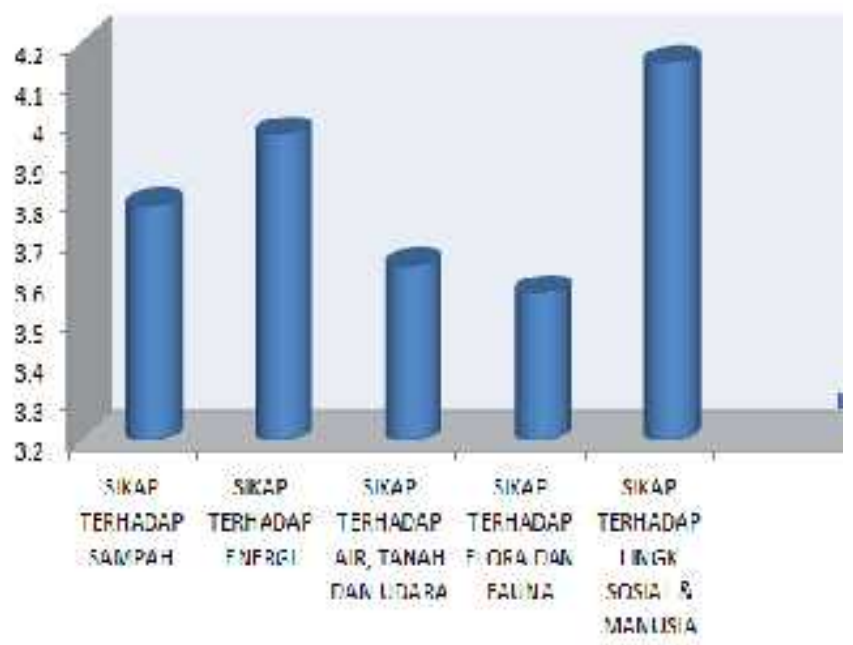

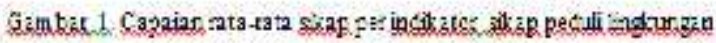

Indikator sikap terhadap lingkungan sosial dan manusia memiliki capaian rata-rata paling tinggi. Sementara indikator sikap terhadap flora dan fauna menunjukkan rata-rata terendah.

Setelah dilakukan perhitungan terhadap capaian sikap per indikator, selanjutnya skor yang didapat setiap peserta didik di konsultasikan pada skala kategori sikap peduli lingkungan. Tabel 6, menyajikan kategori sikap peduli lingkungan peserta didik MAN-1 Pekanbaru. 
Tabel 6. Kategori Sikap peduli lingkungan peserta didik MAN-1 Pekanbaru

\begin{tabular}{llcc}
\hline N0 & Kategori sikap & \multicolumn{2}{c}{ Capaian } \\
\cline { 3 - 4 } & & $\mathrm{f}$ & $\%$ \\
$\mathbf{1}$ & Sangat baik & 28 & 10,37 \\
$\mathbf{2}$ & Baik & 236 & 87.4 \\
$\mathbf{3}$ & Rendah & 6 & 2.22 \\
$\mathbf{4}$ & Apatis/tidak peduli & 0 & 0 \\
& Jumlah & 270 & 100 \\
\hline
\end{tabular}

Dari Tabel 6, dapat dijelaskan bahwa sikap peduli lingkungan peserta didik tertinggi berada pada kategori baik yakni sebesar $87,4 \%$, kategori sangat baik menempati posisi kedua yakni sebesar $10.37 \%$, dan kategori rendah sebesar $2.22 \%$, sementara itu tidak terdapat peserta didik dengan kategori sikap apatis atau tidak peduli.

\section{PEMBAHASAN}

Berdasarkan hasil yang didapatkan dari Tabel 4, untuk setiap item pernyataan sikap dapat dijelaskan bahwa peserta didik MAN-1 Pekanbaru rata-rata menjawab setuju untuk item-item nomor $1,3,4,5,7,9,12,16,18,24$, hal ini terlihat dari capaian rata-rata skor yang berada diatas skala 4. Ini berarti bahwa sebanyak $40 \%$ peserta didik telah memiliki sikap peduli lingkungan yang baik. Sementara itu untuk item pernyataan nomor $2,6,8,10,13$, $14,15,17,19,20,21,22,23$ dan 25, sebagian besar peserta didik masih bersikap ragu-ragu dalam bersikap yakni sebanyak 56\%. Dan terdapat persentase sikap yang rendah untuk pernyataan nomor 11 , yakni sebesar $4 \%$.

Untuk pernyataan sikap per indikator, berdasarkan Tabel 5, didapatkan hasil bahwa capaian skor tertinggi di dapat dari indikator sikap terhadap lingkungan sosial dan manusia yakni sebesar 4.15, hal ini memberi arti bahwa peserta didik telah memiliki sikap peduli terhadap kualitas kesehatan ibu dan anak, peduli terhadap upaya menurunkan angka kematian balita serta upaya melindungi diri dari lingkungan tidak sehat dan pemanasan global.

Indikator tertinggi kedua adalah indikator sikap terhadap energi dengan rata-rata 3,97, hal ini memberi arti bahwa peseta didik telah memiliki sikap yang baik dalam hal menghemat penggunaan energy, mengurangi penggunaan BBM, menggunakan alat elektronik seperlunya, dan peduli terhadap inovasi sumber energy baru.

Indikator tertinggi ketiga adalah indikator sikap terhadap sampah dengan skor rata-rata sebesar 3,79. Hal ini memberi arti bahwa peserta didik telah membuang sampah pada tempatnya, tidak membakar sampah, telah memisahkan sampah sesuai jenisnya, mampu memanfaatkan kembali sampah dan melakukan daur ulang serta meminimalisir produksi sampah.

Indikator tertinggi keempat adalah sikap terhadap udara, tanah, dan air dengan skor ratarata 3,64. Dalam hal ini peserta didik telah memiliki sikap yang baik pada usaha menghemat dalam penggunaan air, membuat area resapan air, menggunakan alat pertanian yang tidak merusak dan memiliki upaya mengurangi pencemaran.

Indikator sikap tertinggi kelima adalah sikap terhadap flora dan fauna dengan skor ratarata 3.57. Pada indikator ini peserta didik telah memiliki sikap yang baik dalam hal mendukung kegiatan konservasi flora fauna langka, menggunakan pestisida alami untuk membunuh hama, konsumsi bahan pangan dengan bijaksana serta ikut menjaga keanekaragaman hayati.

Dari keseluruhan skor sikap peduli lingkungan peserta didik, maka selanjutnya dikonsultasikan pada skala kategori sikap peduli lingkungan yang terdiri atas kategori sangat baik, baik, rendah dan apatis atau tidak peduli. Berdasarkan Tabel 6, sebesar 10,37 \% atau sebanyak 28 orang telah memiliki sikap peduli lingkungan kategori sangat baik. Kategori baik mendominasi sikap peserta didik yakni sebesar $87,4 \%$ atau sebanyak 236 orang. Dan untuk kategori sikap peduli lingkungan rendah sebesar $2,22 \%$ atau sebanyak 6 orang.

Pembentukan sikap pada dasarnya merupakan hasil sosialisasi dan interaksi seseorang dengan lingkungannya yang merupakan perwujudan dari pikiran, perasaan seseorang serta penilaian terhadap objek yang didasarkan pada pengetahuan, pemahaman, pendapat, keyakinan sehingga menghasilkan suatu kecendrungan untuk bertindak (Suharyat, 2014 ). Menurut Soekarjo dan Ukim (2009) apabila ingin mengubah perilaku siswa, maka guru harus berusaha merubah keyakinan atau pandangannya terlebih dulu. Pandangan siswa 
erat kaitan dengan sikap sebagaimana pengertian sikap yang dikemukakan oleh Notoadmodjo dalam Azhar (2015) bahwa sikap merupakan aksi atau respon yang masih tertutup dari seseorang terhadap stimulus atau objek.

Menurut Suharyat (2014) Sikap ditumbuhkan dan dipelajari sepanjang perkembangan peserta didik dalam keterkaitannya dengan objek tertentu. Dalam pembelajaran, sikap sangat berkaitan dengan pengetahuan dan keterampilan yang dimiliki peserta didik. Hal ini penting karena informasi pengetahuan lingkungan yang didapat dari pembelajaran akan diproses diotak melalui serangkaian kegiatan analisis, sintesis dan evaluasi sehingga menghasilkan nilai yang tertuang dalam bentuk sikap.

Ditambahkan oleh Campbell et al., (1999) bahwa selain pengalaman hidup, status sosial ekonomi, dan budaya, sikap sangat ditentukan oleh apa yang diajarkan guru di kelas. Pada pelaksanaan program-program Adiwiyata maka peran guru harus lebih ditingkatkan terutama ketika mengaitkan pelajaran yang diampu dengan masalah-masalah lingkungan. Guru harus mampu mengintegrasikan masalah lingkungan yang terjadi dalam kehidupan sehari-hari dengan memberikan contoh-contoh sederhana sehingga mudah dipahami peserta didik. Guru sebaiknya juga turut diberikan training atau pelatihan untuk dapat meningkatkan kompetensinya sehingga tidak mengalami kesulitan dalam mengintegrasikan isu lingkungan di dalam proses pembelajaran.

Untuk membentuk sikap maka guru harus melaksanakan berbagai model pembelajaran. Landriany (2014) menyatakan bahwa jika sikap peduli lingkungan peserta didik masih rendah dapat disebabkan adanya kesalahan dalam memahami konsep menjaga lingkungan dengan benar. Sementara menurut Esi (2015); Jianpeng et al., (2017) konsep dasar membentuk sikap peduli lingkungan terdiri atas faktor institusi dan management sekolah, pengetahuan konsep siswa, faktor lingkungan, serta strategi pendidikan. Sementara itu penelitian Septian (2016), mengemukakan bahwa untuk memaksimalkan capaian sikap peduli lingkungan, pendidik disarankan menggunakan pendekatan konstruktif dalam pelajaran PLH. Karena untuk menyakinkan seseorang akan pentingnya suatu nilai, diperlukan pemahaman yang dibangun sedikit demi sedikit baik mengenai pemahaman nilai itu sendiri maupun fenomena alam. Sementara itu, Suharyat (2014) menyatakan bahwa untuk merubah sikap peserta didik melalui proses pembelajaran, penyampaian informasi pengetahuan haruslah secara persuasif yakni melalui proses penganalisaan, pensintesisan serta penilaiaan untuk memperoleh keyakinan

Menurut peneliti, selain pelajaran PLH, cara lain yang dapat ditempuh untuk meningkatkan sikap peduli lingkungan adalah memasukkan nilai-nilai agama dan spiritual di semua aspek kegiatan sekolah. Hal ini sesuai dengan tujuan pendidikan nasional dimana pentingnya menanamkan nilai spiritual untuk mewujudkan karakter yang utuh. Penanaman nilai spiritual berfungsi mendorong individu untuk melaksanakan perintah Tuhan dan belajar bertanggung jawab baik bagi dirinya atau pun di masyarakat.

Selain sebagai pendidik, guru juga dapat berperan sebagai modeling dan menanamkan habituasi. Hal ini didukung oleh pendapat Suharyat (2014) bahwa untuk menumbuhkan sikap, guru harus menjadi model, yakni menciptakan situasi dan kondisi yang memungkinkan siswa untuk bersikap peduli terhadap lingkungan, melakukan pembiasaan dan penguatan harus terus dikembangkan khususnya di dalam proses pembelajaran.

Penelitian Tri (2014) menunjukkan bahwa pemberian keteladanan bisa dilakukan guru dengan cara sederhana misalnya menghapus papan tulis setelah pembelajaran selesai, memungut sampah yang berserakan bersama siswa dan ikut serta dalam kegiatan kerja bakti serta selalu memberikan dorongan agar peserta didik dapat mengembangkan nilainilai positif.

$$
\text { Dagiliute dan Andrius (2014) }
$$
menyatakan bahwa perubahan sikap dapat dipengaruhi oleh berbagai faktor seperti usia, jenis kelamin, budaya, motivasi, sarana prasarana yang ada di sekolah dan tekanan sosial. Menjadikan lingkungan sebagai bagian kehidupan seseorang juga dapat meningkatkan sikap kepedulian. Tony Loughland et al., (2003), Liesberg et al., (2011) mendapati bahwa sebagian remaja menjadikan masalah lingkungan hanya sebagai object yang terpisah 
dan berada diluar kehidupan mereka dan menganggap sesuatu yang tidak penting. Hanya sedikit beranggapan bahwa lingkungan menjadi bagian penting yang berpengaruh terhadap kehidupan dan menunjukkan kepedulian.

Menurut Wan roswita (2016) program yang dapat dilakukan sekolah Adiwiyata untuk menumbuhkan sikap peduli lingkungan peserta didik, selain adanya pembelajaran PLH tersendiri, adalah memasukkan PLH pada semua mata pelajaran, mengelola sarana ramah lingkungan, melakukan kegiatan ektra kurikuler ramah lingkungan, dan memperingati hari-hari besar lingkungan. Selain itu pemberian hukuman berupa membersihkan lingkungan sekolah, membuat slogan menjaga lingkungan wajib terapkan bagi peseta didik yang melanggar aturan, untuk menumbuhkan habituasi.

\section{SIMPULAN}

Dari Penelitian yang telah dilakukan dapat disimpulkan bahwa :

1. Sikap peduli lingkungan peserta didik di MAN-1 Pekanbaru berturut-turut paling baik pada indikator sikap terhadap lingkungan sosial dan manusia, sikap terhadap energi, sikap terhadap sampah, sikap terhadap udara tanah dan air dan sikap terhadap flora dan fauna.

2. Kategori Sikap peduli lingkungan peserta didik paling tinggi berada pada baik sebesar $87,4 \%$, kategori sangat baik sebesar 10,37\% dan kategori rendah sebesar 2,22\%.

\section{UCAPAN TERIMA KASIH}

Ucapan terima kasih penulis sampaikan kepada: 1. Kepala MAN-1 Pekanbaru yang telah memberikan fasilitas dalam penelitian ini, 2 . Seluruh peserta didik MAN-1 Pekanbaru, 3. Pihak-pihak yang telah membantu terlaksananya penelitian ini.

\section{DAFTAR PUSTAKA}

Adisendjaja Yusuf. 2008. Pembelajaran Pendidikan Lingkungan Hidup, Belajar dari Alam dan Pengalaman. Jurusan Pendidikan Biologi FPMIPA UPI. Bandung.http://file.upi.edu/Direktori/FP MIPA/JUR._PEND.BIOLOGI/1955121 91980021- P.pdf. Diakses tanggal 15 januari 2019.

.Asrori Mohammad. 2007. Psikologi Pembelajaran. Penerbit CV. Wacana Prima. Bandung.

Azhar., Djahir Basyir., Alfitri. 2015. Hubungan Pengetahuan dan Etika lingkungan dengan Sikap dan Perilaku Menjaga Kelestarian Lingkungan. Program Pasca Sarjana, Universitas Sriwijaya. Jurnal Ilmu Lingkungan Undip, Volume 13-3641.

Bihd Tanjab Barat. 2011. Pengembangan Program Adiwiyata. https://kadafifrank.weebly.com/pengertia n-dan-tujuan-adiwiyata.htm. Diakses 20 Mei 2019.

Campbel, J,W., Waliczek, T. M., Zajicek. 1999. Relationship Between Environmental Knowledge and Environmental Attitude of High School Students, The Journal of Environmental Education, 30:3, 17-21.

Dagiliute R., Andrius Niaura., 2014, Changes Of Students' Environmental Perceptions After The Environmental Science and Biology Courses: VMU Case. ProcediaSocial and Behavioral Sciences 141. 325330. Doi: 10.1016/j.sbspro.2014.05.056

Eşi, M, C. 2015. Didactic Options for the Environmental Education. The 6th International Conference Edu World 2014 "Education Facing Contemporary World Issues". Journal Procedia - Social and Behavioral Sciences. 180: 1380 1385.

doi: 10.1016/j.sbspro.2015.02.281.

Febrianawaty Yusuf \& Ahmad Munandar. 2016. Pengembangan Instrumen Penilaian Sikap Terhadap Lingkungan yang valid dan Reliael bagi siswa SMA. Prosiding seminar Nasional XII Pendidikan Biologi FKIP UNS 2016, 292-296. 
Iswari Dewi \& Suyud Utomo. 2017. Evaluasi Penerapan Program Adiwiyata untuk Membentuk Perilaku Peduli Lingkungan di Kalangan Siswa. Program Pasca Sarjana Universitas Indonesia. Jurnal Ilmu Lingkungan. Volume 153-41.

Jianpeng., Lingyan Yan., Qiuheng shi. 2017. Effect of Perceptions of the Learning Environment and Approaches to Learning on Chinese Undergraduates Learning. Journal Studies in Educational Evaluation. 55(1): 125-134.

Kementerian Lingkungan Hidup. 2008. Panduan Materi Lingkungan Hidup. KLH.

Hari Lingkungan Hidup sedunia. Kementerian Lingkungan Hidup Republik Indonesia. Jakarta.

Kementerian Pendidikan Nasional. 2010. Pedoman Sekolah Tentang Pengembangan Pendidikan Budaya dan Karakter Bangsa. Badan Penelitian dan Pengembangan Pusat Kurikulum.

Kose. 2011. Investigation of Undergraduate Students Environmental Attitudes. International Electronic Journal of Environmental Education. 1 (2): 85-96.

Lake. 2010. Examining Trends in Adolescent Environmental Attitude, Beliefs and Behaviors Acroos 3 Decades. National Institute of health NIH Public access, Environmental Behavior 42(1):61-85

Landriany, E. 2014. Implementasi Kebijakan Adiwiyata Dalam Upaya Mewujudkan Pendidikan Lingkungan Hidup di SMA Kota Malang. Jurnal Kebijakan dan Pengembangan Pendidikan, Volume 2 (1): 82-88.

Liesbeth, K, J, Baartman., Elly de Bruijn. 2011. Integrating Knowledge, Skill and Attitudes: Conceptualising Learning Processes Toward Vocational Competence. Journal Educational Research Review Elsevier 6 : 125-234

Purwanto Ngalim. 2007. Psikologi Pendidikan. PT Remaja Rosdakarya, Bandung

Suharyat Yayat., 2014, Hubungan antara Sikap, Minat dan Perilaku Manusia. Artikel Unisma Bekasi.

Soekarjo, M dan Ukim K., 2009, Landasan kependidikan konsep dan aplikasinya, Bumi aksara. Jakarta
Suryabrata Sumadi. 2002. Psikologi Pendidikan. PT. Raja Grafindo Persada. Jakarta.

Tony Loughland., Anna Reid., Kim walker., Peter Petocz., 2003, Factors influencing Young people's Conceptions of Environment. Environmental Ecducation Research Vol. 9 NO 1. 2003, Carfax Publishing.

Tri Vita, 2016. Pendidikan Lingkungan Hidup dalam Membentuk Sikap Peduli Lingkungan Siswa di SMPN 4 Jombang. Jurnal Kajian Moral dan Kewarganegaraan, Volume 03 Nomor 04, Hal 1153-1167.

Wan roswita, 2016. Keterlibatan Warga Sekolah dalam Pengelolaan Lingkungan Hidup di Sekolah Adiwiyata Tingkat Propinsi. Prosiding "Seminar Nasional Pelestarian Lingkungan dan Mitigasi Bencana, Hal 334-342. Program Pasca Sarjana Universitas Riau.

Wasty Soemanto. 2003. Psikologi Pendidikan. PT. Rineka Cipta. Jakarta. 